\title{
Knowledge, practices, compliance and beliefs of university nursing students' toward hand hygiene: A cross-sectional survey
}

\author{
Dr. HUNG Shuk Yu Maria \\ School of Nursing, \\ Tung Wah College, \\ Hong Kong, \\ China
YAM Wai Shing Samson
Hospital Authority,
Hong Kong,
China
NGAI Cho Ying Cherry
Hospital Authority, Hong Kong,
China

\author{
WONG Yin Yu Ivan \\ Hospital Authority, \\ Hong Kong, \\ China \\ LI Yip King Amy \\ Hospital Authority, \\ Hong Kong, \\ China
}

\begin{abstract}
Nursing students can contribute to healthcareassociated infections if having inadequate knowledge and noncompliance of hand hygiene. Effective hand hygiene is considered the most effective measure for preventing healthcare-associated infections. This study investigated the knowledge, practices, compliance, and beliefs of university nursing students toward hand hygiene. By using a well-validated, self-report hand hygiene questionnaire, a cross-sectional survey was performed. In the convenience sampling, 421 out of 506 questionnaires were returned $(83.2 \%)$. There were $169(40.14 \%), 170(40.38 \%)$ and 82 $(19.48 \%)$ nursing students from Years 1,2 and 3, respectively. The respondents' overall mean score for hand hygiene knowledge was 7.33/10 (SD = 1.52) with an increasing trend of knowledge performance along study year was observed. The hand hygiene practice inventory was $4.76 / 5(\mathrm{SD}=0.303)$. The mean scores for respondents from Years 1,2 and 3 were $4.75(S D=0.367), 4.82$ (SD $=0.20)$ and $4.69(\mathrm{SD}=0.290)$, respectively. The self-reported hand hygiene compliance rate was $88.17 \%(\mathrm{SD}=11.922)$ and the mean score on the health beliefs scale was $4.03 / 5(\mathrm{SD}=\mathbf{0 . 3 4})$. The university nursing students demonstrated moderate knowledge, good practices, a high compliance rate and positive beliefs toward hand hygiene. More effort on educating healthcare professionals about alcohol-based hand rubs and the promotion of hand cream usage to prevent hand-hygiene-induced skin irritations are suggested. Regular training workshops or seminars could be arranged to maintain knowledge levels and cultivate a positive attitude toward hand hygiene.
\end{abstract}

DOI: $10.5176 / 2345-7198 \_5.1 .21$

ISSN 2345-7198

CThe Author(s) 2018. This article is published with open access by the GSTF
Keywords - belief; hand hygiene; knowledge; nursing student; practice

\section{INTRODUCTION}

Healthcare-associated infections (HCAIs) are those acquired by patients through the care they receive in hospitals or healthcare institutions that were not present or incubating during admission [1]. HCAIs pose a substantial risk to patients receiving care, particularly those undergoing prolonged hospital stays, and often result in added costs and preventable deaths [1] HCAIs often occur due to inadequate hand hygiene $(\mathrm{HH})$ compliance among healthcare professionals [2][3]. $\mathrm{HH}$ is considered the most efficient and effective measure for preventing HCAIs, and adequate $\mathrm{HH}$ compliance can significantly reduce the rate of HCAIs [4][5][6]. The WHO has recommended $\mathrm{HH}$ as a primary component of patient safety programs [5], and it has become a significant intervention tactic for decreasing intra-hospital infections [7]. The WHO 5 moments of $\mathrm{HH}$ is a recommended audit tool to assess the $\mathrm{HH}$ compliance. Healthcare professionals' HH compliance has proven key in determining the rate of HCAIs, as their hands are usually considered a major route by which pathogens are spread [4][6].

Nurses and doctors are the largest groups among healthcare professionals required to provide frequent and regular direct patient care. HH knowledge and related beliefs could influence the effectiveness of $\mathrm{HH}$, or lead to non-compliance [8][9]. 
Education and training programs have identified strategies for controlling and preventing HCAIs at the international level [1][10][11]. HH knowledge includes its importance and indications, correct hand-washing and alcohol-rubbing procedures, skin care and glove use [1][2]. As important members of the future professional workforce, nursing and medical students have been provided with $\mathrm{HH}$ education to decrease HCAIs [12][13]. Their awareness of personal HH is essential to patient safety and their own well-being. Several international studies have investigated the knowledge, attitudes and practices of such professionals [14][15][16]17][18]. Inadequate $\mathrm{HH}$ knowledge among nursing students has been mentioned in previous studies conducted in Turkey and Taiwan [19][20], indicating that nursing students can contribute to HCAIs due to insufficient knowledge and non-compliance. The influence of $\mathrm{HH}$ education on undergraduate nursing students and evaluations of $\mathrm{HH}$ knowledge, beliefs and practices have received little attention locally. Thus, a cross-sectional survey study investigating Hong Kong nursing students' HH knowledge, practices, compliance, and beliefs were conducted in a clinical setting. Subsequently, the study results can be used to inform undergraduate nursing curriculum design and compliance strategies. Improving nursing students' $\mathrm{HH}$ compliance could potentially reduce the incidence of HCAIs, which would prevent patients' suffering and save lives.

\section{METHODS}

The conceptual framework of this descriptive study's crosssectional survey was based on the Theory of Planned Behavior, which states that behavior is caused by an individual's internal intention, which is based on three forms of belief: attitude toward the behavior, subjective norms and the amount of perceived control [21]. This framework has been used to predict $\mathrm{HH}$ practices in several studies [8][22][23]. The undergraduate nursing program aims to prepare students for professional careers in nursing with competence to deliver high-quality patient care. Among all four universities offering undergraduate pre-registration nursing programs in Hong Kong, the selected university has the longest history and richest experience in conducting various pre-registration nursing programs with the largest number of nursing students $(>1,000)$. The nursing students have theoretical knowledge and practical skills inputs from subjects in university and clinical practice experience in various hospital settings. Full-time undergraduate nursing students in pre-registration nursing programs and had clinical placement experience in hospitals were recruited for the study. Hand hygiene modules including knowledge and skills are taught in the first year of study before students' clinical placement. A convenience sampling of nursing students from three undergraduate pre-registration nursing programs was recruited from the selected university. A well-validated, selfreported hand hygiene questionnaire (HHQ) developed by van de Mortel [24] was adopted with approval. The questionnaire has been used in various research projects in Europe [14][15].

The HHQ comprises demographic data, $\mathrm{HH}$ knowledge, $\mathrm{HH}$ practices and $\mathrm{HH}$ beliefs items. The demographic data includes questions about the respondents' gender, program stream, year of study and $\mathrm{HH}$ training received. The $\mathrm{HH}$ knowledge section contains 10 multiple-choice questions based on the Centers for Disease Control and Prevention $\mathrm{HH}$ guidelines [2] that are consistent with WHO [1] HH guidelines [5]. The HH practices section includes a 13-item hand hygiene practices inventory (HHPI) measured on a 5-point Likert scale $(1=$ Never, $2=$ Some of the time, $3=$ Half of the time, $4=$ Mostly and $5=$ Always) to examine nursing students' $\mathrm{HH}$ practices. One additional question to estimate the respondents' self $\mathrm{HH}$ compliance with WHO guidelines in the scale of percentage were included. The $\mathrm{HH}$ beliefs section was sub-divided into three parts: a 3-item hygiene importance scale, a 19-item health belief scale (HBS) measured on a 5-point Likert scale ( 1 = Strongly disagree, $2=$ Disagree, $3=$ Not sure, $4=$ Agree and $5=$ Strongly agree) and a scale of 1-10 used to rate $\mathrm{HH}$ importance as an infection control measure.

The content validity of this questionnaire was determined by a panel of three infection control experts based on its readability, accuracy, comprehensiveness of knowledge and relevance of questions and statements. The test-retest coefficients for HHPI and HBS were 0.79 and 0.85 , respectively, and thus considered satisfactory [24]. Inviting 10 undergraduate students from Year 3 of a pre-registration nursing program organized by the selected university in this study, a pilot test was performed.

Prior to data collection, ethical approval was granted by the university's human subject ethics sub-committee. The questionnaires were distributed to the study participants in their classrooms after lectures with prior approval from subject teachers and/or program leaders. A research team member clearly explained the purpose of the study and the respondents' right to join or withdraw, in addition to clarifying their concerns. An information sheet was provided to each respondent along with the questionnaire. All personal information related to them would remain confidential. After completion, the questionnaires were returned to collection box by the respondents. The data were then analyzed using Statistical Package for Social Sciences (SPSS) version 19. Descriptive statistics and a one-way ANOVA were used to perform a between-year comparison of the HH knowledge score, the HHPI, self-reported compliance, the hygiene importance scale, the HBS and the rated importance of $\mathrm{HH}$.

\section{RESULTS}

Of the $506 \mathrm{HHQs}$ that were distributed, 421 (83.2\%) were completed and returned. Of those 421 respondents, 125 (29.69\%) were male and $296(70.31 \%)$ were female. There were $169(40.14 \%), 170(40.38 \%)$ and $82(19.48 \%)$ nursing students from Years 1, 2 and 3, respectively.

\section{1) HH Knowledge}

The respondents' knowledge scores on the $10 \mathrm{HH}$ questions ranged from 2 to 10, with an overall mean of 7.33 out of 10 (SD $=1.52)$ and mean scores of $6.97(\mathrm{SD}=1.66), 7.54(\mathrm{SD}=1.37)$ and $7.61(\mathrm{SD}=1.39)$ for respondents from Years 1, 2 and 3, respectively (Table I). 


\begin{tabular}{|c|c|c|c|c|c|c|c|c|}
\hline \multirow[b]{2}{*}{ Year } & \multirow[b]{2}{*}{$\mathbf{N}$} & \multirow[b]{2}{*}{ Mean } & \multirow[b]{2}{*}{$\begin{array}{c}\text { Std. } \\
\text { Deviation }\end{array}$} & \multirow[b]{2}{*}{$\begin{array}{c}\text { Std. } \\
\text { Error }\end{array}$} & \multicolumn{2}{|c|}{$\begin{array}{l}\text { 95\% Confidence } \\
\text { Interval for Mean }\end{array}$} & \multirow[b]{2}{*}{ Min } & \multirow[b]{2}{*}{ Max } \\
\hline & & & & & $\begin{array}{l}\text { Lower } \\
\text { Bound }\end{array}$ & $\begin{array}{l}\text { Upper } \\
\text { Bound }\end{array}$ & & \\
\hline 1 & 169 & 6.97 & 1.656 & .127 & 6.72 & 7.22 & 2 & 10 \\
\hline 2 & 170 & 7.54 & 1.372 & .105 & 7.33 & 7.75 & 3 & 10 \\
\hline 3 & 82 & 7.61 & 1.386 & .153 & 7.31 & 7.91 & 3 & 10 \\
\hline Total & 421 & 7.33 & 1.520 & .074 & 7.18 & 7.47 & 2 & 10 \\
\hline
\end{tabular}

Among the 10 knowledge questions, Question 10, "Gloves should not be reused when caring for different patients," had the highest correct percentage (94.3\%), whereas Question 9, "Hand creams and lotions are recommended for healthcare workers' hands," had the lowest correct percentage (37.1\%), as shown in Table II. An increasing trend of knowledge performance along study year was observed, and it was statistically significant $(\mathrm{P}<$ $0.001)$.

TABLE II. PERCENTAGE OF CORRECT ANSWERS ON THE KNOWLEDGE QUESTIONS BY NURSING STUDENT

\begin{tabular}{|c|c|c|}
\hline & & Correct \\
\hline Correct Answers of Hand Hygiene Knowledge Items & $\mathbf{N}$ & Percentage \\
\hline $\begin{array}{l}\text { 1. Alcohol-based hand rubs should not be used when hands } \\
\text { are visibly soiled }\end{array}$ & 384 & $91.21 \%$ \\
\hline $\begin{array}{l}\text { 2. Alcohol-based hand rubs are more accessible, time- } \\
\text { saving and effective in reducing bacterial count on the } \\
\text { hands of healthcare workers than washing hands with plain } \\
\text { soaps in hand washing facilities }\end{array}$ & 233 & $55.34 \%$ \\
\hline $\begin{array}{l}\text { 3. Hand hygiene is required following the removal of gloves } \\
\text { after patient contact }\end{array}$ & 361 & $85.75 \%$ \\
\hline $\begin{array}{l}\text { 4. Single use cloth towels and paper towels are acceptable } \\
\text { for drying hands in patient care areas }\end{array}$ & 269 & $63.90 \%$ \\
\hline $\begin{array}{l}\text { 5. Hand hygiene must be performed before patient contact, } \\
\text { following emptying of a drainage reservoir and prior to and } \\
\text { following venipuncture }\end{array}$ & 393 & $93.35 \%$ \\
\hline $\begin{array}{l}\text { 6. When using an alcohol-based hand rub to decontaminate } \\
\text { hands, they should be rubbed together until dry }\end{array}$ & 219 & $52.02 \%$ \\
\hline $\begin{array}{l}\text { 7. Handling paperwork is not one of the recommended } \\
\text { situations for performing hand hygiene }\end{array}$ & 354 & $84.09 \%$ \\
\hline $\begin{array}{l}\text { 8. Hand hygiene is required following contact with the bed } \\
\text { linen of a patient with MRSA }\end{array}$ & 318 & $75.53 \%$ \\
\hline $\begin{array}{l}\text { 9. Hand creams and lotions are recommended for healthcare } \\
\text { workers' hands }\end{array}$ & 156 & $37.05 \%$ \\
\hline $\begin{array}{l}\text { 10. Gloves should not be reused when caring for different } \\
\text { patients }\end{array}$ & 397 & $94.30 \%$ \\
\hline
\end{tabular}

\section{2) HH Practices}

The HHPI of all the respondents on $13 \mathrm{HH}$ items ranged from 2.92 to 5.00 with an overall mean of 4.76 out of $5(\mathrm{SD}=$ 0.303). The mean scores for respondents from Years 1, 2 and 3 were $4.75(\mathrm{SD}=0.367), 4.82(\mathrm{SD}=0.20)$ and $4.69(\mathrm{SD}=0.290)$, respectively (Table III). A fluctuation instead of an upward trend was noted along the study year. The difference in performance between years was found to be statistically significant $(\mathrm{P}=$ 0.007). The HHPI initially increased from Year 1 to Year 2 respondents, but then declined from Year 2 to Year 3 respondents. There was a significant difference between groups, as determined by the one-way $\operatorname{ANOVA}(\mathrm{F}(2,418)=5.068, \mathrm{p}=$ 0.007). Item 8, "After contact with a patient's skin," and Item 11, "Before patient contact," had the lowest mean scores $(4.46$ and 4.33 , comparatively). The respondents' mean scores on all 13 HHPI items were shown in Table IV.

TABLE III. DESCRIPTIVE STATISTIC IN HAND HYGIENE PRACTICE INVENTORY AMONG YEAR OF STUDY OF STUDENTS

\begin{tabular}{|c|c|c|c|c|c|c|c|}
\hline \multirow{2}{*}{ Year } & \multirow{2}{*}{$\mathbf{N}$} & \multirow{2}{*}{ Mean } & \multirow{2}{*}{$\begin{array}{c}\text { Std. } \\
\text { Deviat- } \\
\text { ion }\end{array}$} & \multirow{2}{*}{$\begin{array}{l}\text { Std. } \\
\text { Error }\end{array}$} & \multicolumn{2}{|c|}{$\begin{array}{l}95 \% \text { Confidence } \\
\text { Interval for Mean }\end{array}$} & \multirow[t]{2}{*}{ Range } \\
\hline & & & & & $\begin{array}{l}\text { Lower } \\
\text { Bound }\end{array}$ & $\begin{array}{l}\text { Upper } \\
\text { Bound }\end{array}$ & \\
\hline 1 & 169 & 4.75 & 0.367 & 0.028 & 4.69 & 4.80 & $2.92-5.00$ \\
\hline 2 & 170 & 4.82 & 0.220 & 0.017 & 4.78 & 4.85 & $4.00-5.00$ \\
\hline 3 & 82 & 4.69 & 0.290 & 0.032 & 4.63 & 4.75 & $3.85-5.00$ \\
\hline Total & 421 & 4.76 & 0.303 & 0.015 & 4.73 & 4.79 & $2.92-5.00$ \\
\hline
\end{tabular}

TABLE IV. RESPONDENTS' MEAN SCORES ON 13 HHPI ITEMS

\begin{tabular}{|lc|}
\hline \multicolumn{1}{|c|}{ HHPI: I cleanse my hands: } & Mean (out of 5) \\
\hline 1. After going to the toilet & 4.92 \\
2. Before caring for a wound & 4.89 \\
3. After caring for a wound & 4.92 \\
4. After touching potentially contaminated objects & 4.76 \\
5. After contact with blood or body fluids & 4.95 \\
6. After inserting an invasive device & 4.87 \\
7. Before entering an isolation room & 4.62 \\
8. After contact with a patient's skin & 4.46 \\
9. After exiting an isolation room & 4.71 \\
10. After contact with a patient's secretions & 4.94 \\
11. Before patient contact & 4.33 \\
12. After removing gloves & 4.71 \\
13. If they look or feel dirty & 4.84 \\
\hline
\end{tabular}




\section{3) Self-reported HH Compliance}

The overall mean of the self-reported HH compliance, which ranged from $20-100 \%$ and represented the overall students' $\mathrm{HH}$ compliance with the WHO's HH guidelines, was $88.17 \%$ (SD = 11.922) (Table V). There was no statistically significant difference between groups, as determined by the one-way $\operatorname{ANOVA}(\mathrm{F}(2,418)=2.113, \mathrm{p}=.122)$.

TABLE V. DESCRIPTIVE STATISTIC OF SELF-REPORTED HH COMPLIANCE AMONG DIFFERENT YEAR OF STUDY

\begin{tabular}{|c|c|c|c|c|c|c|c|c|}
\hline & \multirow[b]{2}{*}{$\mathbf{N}$} & \multirow[b]{2}{*}{ Mean } & \multirow[b]{2}{*}{$\begin{array}{c}\text { Std. } \\
\text { Deviation }\end{array}$} & \multirow[b]{2}{*}{$\begin{array}{l}\text { Std. } \\
\text { Error }\end{array}$} & \multicolumn{2}{|c|}{$\begin{array}{l}\text { 95\% Confidence } \\
\text { Interval for Mean }\end{array}$} & \multirow[b]{2}{*}{ Min } & \multirow[b]{2}{*}{ Max } \\
\hline & & & & & $\begin{array}{l}\text { Lower } \\
\text { Bound }\end{array}$ & $\begin{array}{l}\text { Upper } \\
\text { Bound }\end{array}$ & & \\
\hline 1 & 169 & 87.15 & 13.691 & 1.053 & 85.07 & 89.23 & 20 & 100 \\
\hline 2 & 170 & 89.62 & 10.269 & .788 & 88.06 & 91.17 & 20 & 100 \\
\hline 3 & 82 & 87.28 & 10.991 & 1.214 & 84.87 & 89.70 & 30 & 100 \\
\hline Total & 421 & 88.17 & 11.922 & .581 & 87.03 & 89.31 & 20 & 100 \\
\hline
\end{tabular}

\section{4) HH Beliefs}

\section{a) Health Belief Scale (HBS)}

The respondents' scores on the HBS ranged from 2.95 to 5.00 with a mean of 4.03 out of $5(\mathrm{SD}=0.34)$. The mean scores of the respondents from Years 1,2 and 3 were $4.02(\mathrm{SD}=0.36)$, $4.02(\mathrm{SD}=0.34)$ and $4.06(\mathrm{SD}=0.30)$, respectively (Table VI). These results revealed an increase in $\mathrm{HH}$ beliefs as the students progressed into their senior year. The differences in the mean scores between the three years were not statistically significant $(\mathrm{P}=0.647)$.

TABLE VI. Hand Hygiene Beliefs - Health Belief Scale

\begin{tabular}{|c|c|c|c|c|c|c|c|c|}
\hline & \multirow[b]{2}{*}{$\mathbf{N}$} & \multirow[b]{2}{*}{$\begin{array}{c}\text { Mea } \\
\mathbf{n}\end{array}$} & \multicolumn{6}{|c|}{$\begin{array}{l}95 \% \text { Confidence } \\
\text { Interval for Mean }\end{array}$} \\
\hline & & & $\begin{array}{c}\text { Deviatio } \\
\text { n }\end{array}$ & $\begin{array}{l}\text { Std. } \\
\text { Error }\end{array}$ & $\begin{array}{l}\text { Lower } \\
\text { Bound }\end{array}$ & $\begin{array}{l}\text { Upper } \\
\text { Bound }\end{array}$ & Min & $\operatorname{Max}$ \\
\hline 1 & 169 & 4.02 & .360 & .028 & 3.96 & 4.07 & 2.95 & 5.00 \\
\hline 2 & 170 & 4.02 & .339 & .026 & 3.97 & 4.08 & 3.00 & 5.00 \\
\hline 3 & 82 & 4.06 & .304 & .034 & 3.99 & 4.13 & 3.42 & 4.79 \\
\hline Total & 421 & 4.03 & .341 & .017 & 3.99 & 4.06 & 2.95 & 5.00 \\
\hline
\end{tabular}

\section{b) Hygiene Importance Scale}

The respondents' scores on the hygiene importance scale ranged from 1.67 to 5.00, with an overall mean score of 4.39 out of $5(\mathrm{SD}=0.50)$. The means of the individual study years 1,2 , and 3 were $4.37(\mathrm{SD}=0.55), 4.39(\mathrm{SD}=0.46)$ and $4.42(\mathrm{SD}=$ 0.46), respectively (Table VII). Study year was found to be proportional to the mean score, given that the more senior the respondent was, the higher the mean score was. Discrepancies in mean scores between study years were found to be statistically insignificant $(\mathrm{P}=0.753)$.

TABLE VII. HAND Hygiene Beliefs - Hygiene IMPORTANCE Scale

\begin{tabular}{|c|c|c|c|c|c|c|c|c|}
\hline & \multirow[b]{3}{*}{$\mathbf{N}$} & \multirow[b]{3}{*}{ Mean } & \multicolumn{6}{|c|}{ 95\% Confidence } \\
\hline & & & \multirow{2}{*}{$\begin{array}{c}\text { Std. } \\
\text { Deviatio } \\
\text { n }\end{array}$} & \multirow[b]{2}{*}{$\begin{array}{l}\text { Std. } \\
\text { Error }\end{array}$} & \multicolumn{2}{|c|}{ Interval for Mean } & \multirow[b]{2}{*}{ Min } & \multirow[b]{2}{*}{$\operatorname{Max}$} \\
\hline & & & & & $\begin{array}{l}\text { Lower } \\
\text { Bound }\end{array}$ & $\begin{array}{l}\text { Upper } \\
\text { Bound }\end{array}$ & & \\
\hline 1 & 169 & 4.37 & .554 & .043 & 4.28 & 4.45 & 1.67 & 5.00 \\
\hline 2 & 170 & 4.39 & .461 & .035 & 4.32 & 4.46 & 3.00 & 5.00 \\
\hline 3 & 82 & 4.42 & .465 & .051 & 4.32 & 4.52 & 3.33 & 5.00 \\
\hline Total & 421 & 4.39 & .500 & .024 & 4.34 & 4.44 & 1.67 & 5.00 \\
\hline
\end{tabular}

\section{c) Rated Importance of $\mathrm{HH}$}

The respondents' rated importance of $\mathrm{HH}$ ranged from 4 to 10 on a 10 -point scale with a mean of 9.03 out of $10(\mathrm{SD}=1.00)$. The mean rates of the respondents from Years 1, 2 and 3 were $8.97(\mathrm{SD}=1.04), 9.08(\mathrm{SD}=0.95)$ and $9.04(\mathrm{SD}=1.04)$, respectively (Table VIII). The differences in the mean ratings between the respondents from different study years were not statistically significant $(\mathrm{P}=0.59)$.

TABLE VIII. HAND HYGIENE BELIEFS - RATED IMPORTANCE OF HAND HYGIENE

\begin{tabular}{|c|c|c|c|c|c|c|c|c|}
\hline & \multirow[b]{2}{*}{$\mathbf{N}$} & \multirow[b]{2}{*}{ Mean } & \multirow[b]{2}{*}{$\begin{array}{c}\text { Std. } \\
\text { Deviation }\end{array}$} & \multirow[b]{2}{*}{$\begin{array}{l}\text { Std. } \\
\text { Error }\end{array}$} & \multicolumn{2}{|c|}{$\begin{array}{l}\text { 95\% Confidence } \\
\text { Interval for Mean }\end{array}$} & \multirow[b]{2}{*}{ Min } & \multirow[b]{2}{*}{ Max } \\
\hline & & & & & $\begin{array}{l}\text { Lower } \\
\text { Bound }\end{array}$ & $\begin{array}{l}\text { Upper } \\
\text { Bound }\end{array}$ & & \\
\hline 1 & 169 & 8.97 & 1.043 & .080 & 8.81 & 9.13 & 5 & 10 \\
\hline 2 & 170 & 9.08 & .951 & .073 & 8.94 & 9.23 & 4 & 10 \\
\hline 3 & 82 & 9.04 & 1.036 & .114 & 8.81 & 9.26 & 4 & 10 \\
\hline Total & 421 & 9.03 & 1.004 & .049 & 8.93 & 9.12 & 4 & 10 \\
\hline
\end{tabular}

\section{DISCUSSION}

The study results for HH knowledge demonstrated moderate knowledge (7.33/10) with a continuous increase in the knowledge level of nursing students throughout their years of study, as indicated by the increase in respondents' mean scores in each study year. This directly proportional trend is consistent with the results of previous studies. Kennedy and Burnett [25] reported that $\mathrm{HH}$ understanding and knowledge were higher among senior nursing students than among their junior counterparts. Similarly, van de Mortel and her colleagues [15], 
using the same originally developed HHQ, showed that Italian nursing students who had studied for longer possessed a higher level of $\mathrm{HH}$ knowledge than those who were less educated. She concluded that clinical experience can facilitate the continuous improvement of nursing students' $\mathrm{HH}$ knowledge throughout the duration of their studies.

In this study, the mean knowledge score (7.33/10) of the nursing student respondents was like those studies conducted in Greece (with a mean 7.37/10) [14], in Singapore (with a mean of 7.5/10) [26] and in Jordan (with a mean of 7.9/10) [27] but higher than those studies conducted in Italy (with a mean of 5.25/10) [15] and in United Kingdom (with a mean of 5.20/10) [28]. However, the respondents' knowledge about alcohol-based hand rubs was comparatively inadequate. A low correct percentage $(<60 \%)$ of respondents' knowledge was noted for three of the questions in this study, all of which were related to alcohol-based hand rubs. Unsatisfactory results for two questions revealed that the nursing respondents were not aware of how long the cleansing effect of alcohol hand rubs lasts. Another question reflected a common misunderstanding regarding the damage to hands caused by traditional handwashing and alcohol hand rubs. Such findings are in agreement with similar research results indicating that medical and nursing students might have inadequate knowledge of alcohol hand rubs and conservative hand-washing [15][23][28]. Hand cream usage is recommended to reduce skin dryness or breakdown after frequent $\mathrm{HH}$ [1]. It is necessary to correct these misconceptions and provide correct information, as they could increase the risk of $\mathrm{HH}$ noncompliance and thus the transmission of HCAIs [7][23]. Hence, future undergraduate curricula for nursing and medical students should emphasize the correct indications and use of alcohol-based hand rubs at their clinical settings.

However, HH knowledge was not the only factor that affected $\mathrm{HH}$ behavior and compliance [7][23]29]. A recent study in Saudi investigated the predictors of $\mathrm{HH}$ practice among nursing students demonstrated that having a good attitude toward $\mathrm{HH}$, being male, and being aware that $\mathrm{HH}$ could prevent HCAIs were some significant predictors of $\mathrm{HH}$ practice [29]. Thus, having adequate knowledge with regular enhancement programs in clinical settings could instill a positive impact on $\mathrm{HH}$ practice.

The mean score for the HHPI was 4.75/5, which was converted to $95 \%$. This practice rate is considered high when compared with other Asian and local studies: $72 \%$ in Taiwanese nursing students [20], 82.1\% in South Korean nursing students [23], 83\% of Hong Kong's registered nurses [30] and $85 \%$ in China's registered nurses [31]. The increase in the $\mathrm{HH}$ practice rate might be due to the increased global concerns and active promotion of $\mathrm{HH}$ practices in preventing HCAIs over the past decade, following the SARS scare in 2003 and the H1N1 epidemics in 2009.

As the mean HHPI score shows, the Year 2 respondents exhibited more frequent $\mathrm{HH}$ practices than their Year 1 counterparts, but the practice rate dropped from Year 2 to Year 3. The study respondents mostly took part in simple nursing routines during clinical placements while they were still junior and inexperienced. Thus, junior nursing students are critical to the input of HH knowledge [7]. In Hong Kong, most of the nursing students of junior years such as Year 1 or 2 are clinically supervised by university supervisors whereas nursing students of senior years are supervised by hospital mentors. The presence of university or institution supervisors also significantly increases $\mathrm{HH}$ practices among nursing students, who tend to maintain harmonious relationships with their supervisors through HH compliance [7][26][32]. The effects of mentors and other healthcare professionals in clinical settings have proven more powerful than university faculty members, though nursing students have been taught appropriate $\mathrm{HH}$ practices by faculty members in university [17][23]. Given the importance of fitting into one's work culture in different hospital clinical settings, some students may be uncomfortable with challenging inappropriate or incorrect $\mathrm{HH}$ practices [7][17][33]. However, Hinkin and Cutter [17] reported that more than half of their study respondents followed the advice provided by the university instead of following the bad practices of hospital mentors.

Inappropriate $\mathrm{HH}$ practices may be observed or learned by nursing students during their clinical attachments as they progress and their university or institution supervisors spend less time with them. They work with clinical mentors and ward staff members and are responsible for more nursing routines and procedures. Studies on the increased workload and time strain experienced by nursing students during their clinical placements [26][34] have found that a lighter workload is associated with increased $\mathrm{HH}$. However, a local survey reported serious nursing workforce shortage in hospitals in recent decades [35] that might affect the nursing service in Hong Kong. This considerable high patient to low nurse ratio was one of the major causes of heavy workload and time strains that might affect student learning and HH practices.

The overall mean of self-reported $\mathrm{HH}$ compliance was high among the respondents in this study (mean 88.17\%) which were similar to the hand hygiene compliance rate (between $78.93 \%$ and $95.3 \%$ ) concluded in previous nursing students' studies [15][19][23][26][27]. Self-reporting might not be an appropriate approach in research, as its lack of objectivity and fairness that can promote self-deception [36] and, subsequently, assessment flaws [37] and overestimation of $\mathrm{HH}$ practices. In contrast, observational bias may affect $\mathrm{HH}$ compliance through the Hawthorne effect in another study [38], thus a mixed method for evaluating $\mathrm{HH}$ compliance could be suggested for balancing the bias in future studies.

The HBS result was high (4.03/5) compared with van de Mortel's [14][15] previous results using the same questionnaire (3.27/5 and 3.92/5, respectively). This high HBS result indicated that nursing students have positive $\mathrm{HH}$ beliefs. The respondents agreed that $\mathrm{HH}$ should be an important part of the undergraduate nursing curriculum, and generally confirmed the importance of $\mathrm{HH}$ as an infection control measure in clinical settings. The high HBS score also indicated that students possess positive $\mathrm{HH}$ beliefs in relation to preventing HCAIs. These findings are in line with those of previous studies. For instance, a study of university pre-registration nursing students in the United Kingdom reported that the majority of the respondents $(83.7 \%)$ recognized that hands are the most significant route of pathogen transmission, and $93 \%$ of respondents knew that $\mathrm{HH}$ is the most effective strategy for preventing the spread of infection [17]. Similarly, $89.8 \%$ of a sample of nursing students in Jordan 
reported positive beliefs about $\mathrm{HH}$ as an infection control precaution [39]. Indeed, a good attitude toward $\mathrm{HH}$ was recognized as the significant predictor of $\mathrm{HH}$ practice [29]. If the nursing students have a positive attitude and beliefs about the benefits of $\mathrm{HH}$ and are aware of the consequences of poor compliance, they would practice the $\mathrm{HH}$ more effectively [27].

The items with lower HBS scores indicated that although the nursing students understood the importance of performing $\mathrm{HH}$, some questioned whether to follow senior healthcare professionals' $\mathrm{HH}$ behavior and reported that they might not have the confidence to challenge and promote $\mathrm{HH}$ practices among other healthcare professionals. They ranked $\mathrm{HH}$ practices below patients' needs, echoing a similar result from van de Mortal et al. [15]. This ambivalence can be explained by Social Cognitive Theory [40], whereby personal factors such as a lack of self-efficacy and social factors such as the fear of challenging a senior coworker can hinder HH behavior [17].

Convenience sampling with a self-reported questionnaire was used for its convenience and economy, and the respondents were recruited from one large university were the study limitation. These factors might hinder the generalizability of the results, making applications to other universities difficult. Regarding the study design, the use of a self-reported questionnaire might have led to an overestimation of real practices, resulting in unreliable findings. Thus, a method that integrates observation could be beneficial and is suggested for future study. Conducting individual or group interviews to clarify issues or to add further related information could be considered in future studies. Moreover, unevenly distributed numbers of sampling in different years may have affected the results. Thus, future research study with larger sample size and more settings with the use of the mixed method of self-reported and observation approach as data collection are suggested.

\section{CONCLUSIONS}

The respondents exhibited satisfactory knowledge, good practices and compliance, positive beliefs and a high compliance rate with respect to the $\mathrm{WHO}$ guidelines on $\mathrm{HH}$, but revealed weak knowledge about alcohol-based hand rubs. More emphasis should be placed on education about using alcohol-based hand rubs and promoting the use of hand cream to prevent skin irritations stemming from HH. Regular workshops or seminars could be organized to maintain knowledge levels and cultivate a positive attitude toward $\mathrm{HH}$. Further evaluation studies on $\mathrm{HH}$ and infection control practices among healthcare professionals such as medical students and healthcare assistants are encouraged in order to prevent or decrease HCAIs and patients' suffering.

\section{ACKNOWLEDGMENT}

Special thanks to Dr. van de Mortel for approval in using the hand hygiene questionnaire. Thanks for those who contributed during the research process including CHC, LSC, CHI, SKL, and SMD.

\section{REFERENCES}

[1] World Health Organization. WHO guidelines on hand hygiene in health care: first global patient safety challenge. Clean care is safer care. World Health Organization, 2009.

[2] Boyce JM, Pittet D. Guideline for hand hygiene in health-care settings: Recommendations of the Healthcare Infection Control Practices Advisory Committee and the HICPAC/SHEA/APIC/IDSA Hand Hygiene Task Force. American Journal of Infection Control. 2002; 30(8): S1-S46.

[3] Erasmus V, Daha TJ, Brug H, Richardus JH, Behrendt MD, Vos MC, van Beeck EF. Systematic review of studies on compliance with hand hygiene guidelines in hospital care. Infection Control. 2010; 31(03): 283-294.

[4] Backman C, Zoutman DE, Marck PB. An integrative review of the current evidence on the relationship between hand hygiene interventions and the incidence of health care-associated infections. American Journal of Infection Control. 2008; 36(5): 333-348.

[5] Pittet D, Allegranzi B, Boyce J. The World Health Organization guidelines on hand hygiene in health care and their consensus recommendations. Infection Control. 2009; 30(7): 611-622.

[6] Ellingson K, Haas JP, Aiello AE, Kusek L, Maragakis LL, Olmsted RN, VanAmringe M. Strategies to prevent healthcare-associated infections through hand hygiene. Infection Control \& Hospital Epidemiology. 2014; 35(08): 937-960.

[7] Barrett R, Randle J. Hand hygiene practices: Nursing students' perceptions. Journal of Clinical Nursing. 2008; 17(14): 1851-1857.

[8] Elliott P. Recognizing the psychosocial issues involved in hand hygiene. Journal of the Royal Society for the Promotion of Health. 2003; 123(2): 88-94.

[9] McLaughlin AC, Walsh F. Self-reported reasons for hand hygiene in 3 groups of health care workers. American Journal of Infection Control. 2012; 40(7): 653-658.

[10] Allegranzi B, Pittet D. Role of hand hygiene in healthcare-associated infection prevention. Journal of Hospital Infection. 2009; 73(4): 305-315.

[11] Al-Tawfiq JA, Abed MS, Al-Yami N, Birrer RB. Promoting and sustaining a hospital-wide, multifaceted hand hygiene program resulted in significant reduction in health care-associated infections. American Journal of Infection Control. 2013; 41(6): 482-486.

[12] Kelcíkova S, Skodova Z, Straka S. Effectiveness of hand hygiene education in a basic nursing school curricula. Public Health Nursing. 2012; 29(2): 152-159.

[13] Al-Hussain M, Darawad M. Compliance of nursing students with infection prevention precautions: Effectiveness of a teaching program. American Journal of Infection Control. 2013; 41(4): 332-336.

[14] van de Mortel, TF, Apostolopoulou E, Petrikkos G. A comparison of the hand hygiene knowledge, beliefs, and practices of Greek nursing and medical students. American Journal of Infection Control. 2010; 38(1): 7577.

[15] van de Mortel, TF, Kermode S, Progano T, Sansoni J. A comparison of the hand hygiene knowledge, beliefs and practices of Italian nursing and medical students. Journal of Advanced Nursing. 2012; 68(3): 569-579.

[16] D'Alessandro D, Agodi A, Auxilia F, Brusaferro S, Calligaris L, Ferrante M, Righi E. Prevention of healthcare-associated infections: Medical and nursing students' knowledge in Italy. Nurse Education Today. 2014; 34(2): 191-195.

[17] Hinkin J, Cutter J. How do university education and clinical experience influence pre-registration nursing students' infection control practice? A descriptive, cross-sectional survey. Nurse Education Today. 2014; 34(2): 196-201.

[18] Nair SS, Hanumantappa R, Hiremath SG, Siraj MA, Raghunath P. Knowledge, attitude, and practice of hand hygiene among medical and nursing students at a tertiary health care center in Raichur, India. ISRN Preventive Medicine. 2014.

[19] Çelik S. \& Koçaşlı, S. Hygienic hand washing among nursing students in Turkey. Applied Nursing Research. 2008; 21(4): 207-211.

[20] Wu CJ, Gardner G, Chang AM. Nursing students' knowledge and practice of infection control precautions: An educational intervention. Journal of Advanced Nursing. 2009; 65(10): 2142-2149. 
[21] Ajzen I, Madden TJ. Prediction of goal-directed behavior: Attitudes, intentions, and perceived behavioral control. Journal of Experimental Social Psychology. 1986; 22(5): 453-474.

[22] O'Boyle CA, Henly SJ, Larson E. Understanding adherence to hand hygiene recommendations: The theory of planned behavior. American Journal of Infection Control. 2001; 29(6): 352-360.

[23] Jeong, Sun Young, and Kyung Mi Kim. Influencing factors on hand hygiene behavior of nursing students based on the theory of planned behavior: A descriptive survey study. Nurse education today. 2016; 36: 159-164.

[24] van de Mortel TF. Development of an instrument to assess health care students' hand hygiene knowledge, beliefs and practices. Australian Journal of Advanced Nursing. 2009; 26(3), 9-16.

[25] Kennedy, M., and E. Burnett. "Hand hygiene knowledge and attitudes: comparisons between student nurses." Journal of Infection Prevention. 2011; 12(6): 246-250.

[26] Nasirudeen A, Koh JW, Lau ALC, Li W, Lim LS, Ow CYX. Hand hygiene knowledge and practices of nursing students in Singapore. American Journal of Infection Control. 2012; 40(8): e241-e243.

[27] Al-Khawaldeh, O. A., Al-Hussain, M., \& Darawad, M. Influence of nursing students handwashing knowledge, beliefs, and attitudes on their handwashing compliance. Health. 2015; 7(5), 572.

[28] Mann CM, Wood A. How much do medical students know about infection control? Journal of Hospital Infection. 2006; 64(4): 366-370.

[29] Cruz, Jonas Preposi, and Meshrif Ahmad Bashtawi. "Predictors of hand hygiene practice among Saudi nursing students: A cross-sectional selfreported study." Journal of Infection and Public Health. 2015.

[30] Chan R, Molassiotis A, Chan E, Chan V, Ho B, Lai C, Lam P, Shit F, Yiu I. Nurses' knowledge of and compliance with universal precautions in an acute care hospital. International Journal of Nursing Studies. 2002; 39(2): 157-163.
[31] Chan MF, Ho A, Day MC. Investigating the knowledge, attitudes and practice patterns of operating room staff towards standard and transmission - based precautions: Results of a cluster analysis. Journal of Clinical Nursing. 2008; 17(8): 1051-1062.

[32] Snow M, White GL, Alder SC, Stanford JB. Mentor's hand hygiene practices influence student's hand hygiene rates. American Journal of Infection Control. 2006; 34(1): 18-24.

[33] Ward DJ. Infection control in clinical placements: Experiences of nursing and midwifery students. Journal of Advanced Nursing. 2010; 66(7): 15331542 .

[34] Scheithauer S, Haefner H, Schwanz T, Lopez-Gonzalez L, Bank C, Schulze-Röbbecke R, Lemmen SW. Hand hygiene in medical students: Performance, education, and knowledge. International Journal of Hygiene and Environmental Health. 2012; 215(5): 536-539.

[35] Association of Hong Kong Nursing Staff. HA Nurse Human Resources Survey 2014 [in Chinese]. [Cited 3 January 2016]. Available from URL:http://www.nurse.org.hk/media/contentbuilder/upload/c04041408. pdf.

[36] Trunnell EP, White Jr GL. Using behavior change theories to enhance hand hygiene behavior. Education for Health (Abingdon, England). 2005; 18(1): 80 .

[37] Cole M. Exploring the hand hygiene competence of student nurses: A case of flawed self-assessment. Nurse Education Today. 2009; 29(4): 380-388.

[38] van de Mortel, TF, Murgo M. An examination of covert observation and solution audit as tools to measure the success of hand hygiene interventions. American Journal of Infection Control. 2006; 34(3): 95-99.

[39] Darawad MW, Al-Hussami M. Jordanian nursing students' knowledge of, attitudes towards, and compliance with infection control precautions. Nurse education today. 2013; 33(6): 580-583.

[40] Bandura A. Social foundations of thought and action: A social cognitive theory. Prentice-Hall, 1986. 